\title{
EFFECTS OF TULSI LEAF EXTRACT ON BODY WEIGHT GAIN IN BROILER PRODUCTION
}

\author{
M. N. $\operatorname{Hasan}^{1 *}$, M. Mostofa ${ }^{1}$, M. G. Sorwar ${ }^{1}$, M. T. Hasan ${ }^{2}$, K. Das ${ }^{3}$ and D. M. N. Hossain ${ }^{3}$ \\ ${ }^{1}$ Department of Pharmacology, Bangladesh Agricultural University, Mymensingh-2202, Bangladesh; ${ }^{2}$ Department of \\ Medicine, Sylhet Agricultural University, Sylhet, Bangladesh; ${ }^{3}$ Department of Medicine, Surgery and Obstetrics, \\ Faculty of Animal Science and Veterinary Medicine, Patuakhali Science and Technology University, Dumki-8602, \\ Patuakhali, Bangladesh
}

\begin{abstract}
The objective of this research was to evaluate the effect of tulsi leaf (Ocimum sanctum) extract supplementation in drinking water as a growth promoter in broiler chickens. A total of 40 Cobb-500 broiler chicks (day-old) were purchased from local hatchery (Nourish Poultry and Hatchery Ltd.). After seven days of acclimatization chicks were randomly divided into two groups, A (n=20) and B $(n=20)$. The group A was kept as a control and not treated. The group B was supplemented with tulsi leaf extract with feed and water. Weekly observations were recorded for live body weight gain up to $5^{\text {th }}$ weeks and hematological tests were performed at $35^{\text {th }}$ day's age of broiler to search for hematological changes between control (A) and treatment (B) groups. The initial body weight of groups A and B on 1st day of this experiment were $41.00 \pm 1.78 \mathrm{gm}$ and $41.50 \pm 2.35$ gm, respectively and after $35^{\text {th }}$ day of experiment final body weight were $1640 \pm 74.83 \mathrm{gm}$ and $1920 \pm 33.91 \mathrm{gm}$, respectively and economics of production were analyzed and found that net profit per broiler was Tk. 21.46 and Tk. 32.29, respectively. The treatment group B was recorded statistically significant (at 1\% level) increased (16.97\%) for live body weight than that of control group A. The hematological parameters total erythrocyte count (TEC), erythrocyte sedimentation rate (ESR), packed cell volume (PCV) and hemoglobin (Hb) estimation value of treatment group shows significant difference, while hemoglobin $(\mathrm{Hb})$ estimation does not show significant difference from control group. The results suggest that better growth performance could be achieved in broilers supplemented with tulsi leaf extract.
\end{abstract}

Keywords: Tulsi leaf, growth promoter, broiler.

\section{INTRODUCTION}

The poultry production systems led to marked increase in the production of poultry meat and eggs throughout the world (Armstrong, 1986). It has triggered the discovery and widespread use of a number of "feed additives". The term feed additives is applied in a broad sense, to all products other than those commonly called feedstuffs, which could be added to the ration with the purpose of obtaining some special effects. The main objective of adding feed additives is to boost animal performance by increasing their growth rate, better-feed conversion efficiency, greater livability and lowered mortality in poultry birds. These feed additives are termed as "growth promoters" and often called as non-nutrient feed additives (Singh and Panda, 1992). Many synthetic drugs and growth promoters are supplemented to the broilers to effect rapid growth, but their use have shown many disadvantages like high cost, adverse side-effect on health of birds and long residual properties etc. (Bhujbal et al., 2009). Growth promoters are chemical and biological substances, which are added to livestock food and in this way realize better production and financial results. European Commission banned four commonly used feed antibiotics: monensin sodium, salinomycin sodium, avilamycin, flavophospholipol (Banerjee, 1998). The banning of antibiotic growth promoter (AGP) will affect the poultry and livestock industry (Ashayerizadeh et al., 2009). To minimize the loss in growth, there is a need to find alternative to AGP. There are a number of nontherapeutic alternatives such as enzymes, inorganic acids, probiotics, prebiotics and herbs (Banerjee, 1998). Since ancient times herbs and their essentials have been known for their varying degree of antimicrobial activity (Juven et al., 1994). More recently, medicinal plants extracts were developed and proposed for use in food as natural antimicrobials (Hsieh et al., 2001). Tulsi has attracted worldwide prominence due to its vast range of medicinal properties without showing any adverse effects. Tulsi also promotes growth and feed efficiency of birds because of their antibacterial properties (WHO, 1997).

Plants are the oldest friends of mankind. In modern animal feeding, they are forgotten because of use of antimicrobial growth promoters but due to the prohibition of most AGP plants extracts have gained interest in animal feed strategies (Borris, 1996). The risk of the presence of antibiotic residues in milk and meat and their harmful effects on human has led to their prohibition for use in animal feed in the European Union (Khanna and Bhatia, 2003). Medicinal plants have been used for centuries before the advent of orthodox medicine (Demir et al., 2005). The medicinal values of these plants lie in their component phytochemicals, which produce definite physiological actions on the human body (Sen, 1993). 


\section{N. Hasan and others}

The juice of fresh leaves is also given to patients to treat chronic fever, dysentery, hemorrhage and dyspepsia (Gatne et al., 2008). A decoction of tulsi leaf is a popular remedy for cold. Tulsi leaves also check vomiting and has been used as anthelmintic (Borris, 1996). As a prophylactic against malaria, fresh tulsi leaves are taken with black paper in the morning (Vinod-Krishna et al., 2007). Ayurvedic preparation containing tulsi (Ocimum sanctum), garlic (Allium stivum), black pepper (Piper nigram) and cloves (Curcuna longa) have been shown to possess antimalarial activity against Plasmodium vivex and Plasmodium falciparum (Jadhav et al., 2005). As far as its antimalarial effect is concerned tulsi extracts and essential oil have also been found to possess insecticidal and larvicidal activities against mosquitoes. Herbal preparations containing tulsi have been suggested to shorten the course of illness, clinical symptoms and biochemical parameters in patients suffering from viral hepatitis. The leaf juice of tulsi along with triphala is used in ayurvedic eye drop preparations recommended for glaucoma, cataract, chronic conjunctivitis and other painful eye diseases. Tulsi also possesses antifungal activity against Aspergillus niger. Aqueous extract of tulsi is found effective in patients suffering from viral encephalitis (Nath et al., 2012). Aqueous decoction of whole plant lowers the blood sugar (glucose) level and is said to control Diabetes mellitus (Khanna and Bhatia, 2003). The investigation was therefore, designed to study the hematological effects of tulsileave extract in broiler, with a view to establishing effect of tulsi leaf extract as a growth promoter and its safety in broiler chickens. The main objective of adding feed additives is to boost animal performance by increasing their growth rate, better-feed conversion efficiency, greater livability and lowered mortality in poultry birds.

\section{MATERIALS AND METHODS}

This study was executed at the Department of Pharmacology, Bangladesh Agricultural University (BAU), Mymensingh during the period from $26^{\text {th }}$ October, 2015 to $29^{\text {th }}$ November, 2015. A total of 40 Cobb-500 broiler chicks (day-old) purchased from a local hatchery (Nourish Poultry and Hatchery Ltd) were used in the experiment. They were kept on the floor in isolated pens and fed commercial ration and water as per instruction. All birds were provided same management conditions like floor space, temperature, relative humidity, ventilation and light. Immediately after entering into the shed all chicks were given vitamin $\mathrm{C}$ and glucose to prevent the stress for transportation. The broiler chicks were kept in the same compartment for 7 days and brooding temperature were correctly maintained. Optimum light was provided daily throughout the experimental period. The chicks were brooded at $35^{\circ} \mathrm{C}$ during first week and thereafter; the temperature was reduced by $3^{\circ} \mathrm{C}$ every week until the temperature reached to the room temperature. The litter management was also done very carefully. The starter and finisher broiler rations were supplied to the broiler chicken appropriately. A weighed amount of the ration was offered to the birds twice a day and the left over feed was collected to calculate feed consumption of the birds. The weight of breast and thigh were recorded along with the vital organs (heart, liver and gizzard) etc.

Mature and disease free tulsi leaves were collected from BAU Botanical Garden. After washing, the fresh leaves were cut into small pieces by simple scissors and dried in oven and $20 \mathrm{gm}$ mixed with added water made up to 1 litter. Then boiled it made up to 1 liter and stored in a refrigerator at $4{ }^{\circ} \mathrm{C}$ to preserve the active ingredients of juice (Khatun et al., 2013). After 7 days all the 40 broiler chicks were randomly divided into 2 groups $A(n=20)$ and $B(n=20)$. Treatment group $B(n=20)$ received mixture of tulsi leaf extract $(2 \%$ each in drinking water). All the chicks of treated and control groups were closely observed for 35 days.

Broilers chicks of control and treatment groups were weighed with digital weighing machine. The weight of broiler chickens was taken weekly. Mean live weight gains of each group of chicken on $1^{\text {st }}, 7^{\text {th }}, 14^{\text {th }}, 21^{\text {st }}, 28^{\text {th }}$ and $35^{\text {th }}$ days were recorded. Blood samples were collected from wing vein of chicken of both control and treated groups at $35^{\text {th }}$ days to study hematological parameters according to the method described by Lamberg and Rothstein (1977).

\section{Statistical analysis}

The data were analyzed statistically between control and treated groups by student's t-test. The differences were considered statistically significant at $5 \%$ level $(\mathrm{P}<0.05)$.

\section{RESULTS AND DISCUSSION}

The body weight gains were found higher in treated group compared to non treated control group (Table 1). Similarly, Mazhar-IIahi et al. (2007) reported increase in feed efficiency in tulsi fed groups, which is in agreement with the findings of the present study. Mollah et al. (2012) reported significant increase in the live weight of broilers compared with control group. Statistical analysis of the data did not show any difference between the relative gizzard, spleen and pancreas weights of the birds of different feeding groups using ration with or without supplementation of tulsi leaf extract (Table 2). Supplementation of tulsi leaf extract in the treatment caused improvement in the feed efficiency as compared to that of control group (Carmona-Fernandez et al., 2009).

The average rearing costs of broilers in two groups were Tk. 178.00 and Tk. 188.00 for A and B groups respectively (Table 3). Miscellaneous cost summed up Tk. 20.00 per broiler, which included the estimated cost of electricity, litter and disinfectant. The average live weight/broiler in groups A and B were $1.640 \mathrm{~kg}$ and $1.920 \mathrm{~kg}$ respectively. The broilers were sold in live weight basis at the rate of Tk. 130.00/kg. The net profit $/ \mathrm{Kg}$ live weight in the respective group was found to be Tk.21.46 and Tk. 32.29 respectively. 
Table 1. Live weight gain, feed consumption and feed conversion ratio of broilers fed $2 \%$ of tulsi leave extract from 2 to 5 weeks of age

\begin{tabular}{|c|c|c|c|c|}
\hline \multirow[t]{2}{*}{ Variables } & \multicolumn{2}{|c|}{ Average weight (Mean \pm SEM) } & \multirow{2}{*}{$P$ value } & \multirow{2}{*}{ Significance level } \\
\hline & Control & Tulsi & & \\
\hline Initial live weight $(\mathrm{g})$ on $1^{\text {th }}$ day & $41.00 \pm 1.78$ & $41.50 \pm 2.35$ & .000 & ** \\
\hline Final live weight $(\mathrm{g})$ on $35^{\text {th }}$ day & $1640 \pm 74.83$ & $1920 \pm 33.91$ & .000 & $* *$ \\
\hline Weight gain from $7^{\text {th }}$ day $(\mathrm{g})$ & $1511.13 \pm 41.76$ & $1792.5 \pm 51.22$ & .000 & $* *$ \\
\hline Feed consumption $(\mathrm{g})$ & $14000 \pm 35.49$ & $14080 \pm 52.29$ & .000 & $* *$ \\
\hline FCR & 1.98 & & 1.71 & \\
\hline
\end{tabular}

** Significant $(\mathrm{p}<0.05)$

Table 2. Dressing percentages, relative giblet weight (heart, gizzard, liver, spleen and pancreas) weight of broilers supplemented with tulsi leaf extract from 2-5 weeks of age

\begin{tabular}{|c|c|c|c|c|}
\hline \multirow[t]{2}{*}{ Variables } & \multicolumn{2}{|c|}{ Average value $($ Mean \pm SEM $)$} & \multirow[t]{2}{*}{$\mathrm{P}$ value } & \multirow[t]{2}{*}{ Significance level } \\
\hline & Control & Tulsi & & \\
\hline Dressing percentage & $64.410 \pm 0.414$ & $64.470 \pm 0.961$ & 0.931 & - \\
\hline Relative heart weight & $0.420 \pm 0.032$ & $0.501 \pm 0.032$ & 0.001 & $* *$ \\
\hline Relative gizzard weight & $1.460 \pm 0.034$ & $1.440 \pm 0.014$ & 0.605 & - \\
\hline Relative liver weight & $2.530 \pm 0.034$ & $2.610 \pm 0.032$ & 0.002 & $* *$ \\
\hline Relative spleen weight & $0.120 \pm 0.011$ & $0.130 \pm 0.015$ & 0.011 & $* *$ \\
\hline Relative pancreas weight & $0.230 \pm 0.011$ & $0.250 \pm 0.017$ & 0.001 & $* *$ \\
\hline
\end{tabular}

** Significant $(\mathrm{p}<0.05)$; relative weight $(\mathrm{g})=$ Weight of organ/Live body weight of bird X 100; dressing \% = Dress weigh of bird/Live weigh of bird

Table 3. Cost-benefit analysis of broiler production by using feed supplemented with tulsi leaf extract from 2-5 weeks of age

\begin{tabular}{lcc}
\hline \multicolumn{1}{c}{ Description } & Group-A & Group-B \\
\hline Cost/chick (tk) & 30.00 & 30.00 \\
Average feed consumed (Kg)/chicks & 3.200 & 3.200 \\
Feed price/kg (tk) & 40.00 & 40.00 \\
Cost of herbal growth promoters (tk) & 0.00 & 10.00 \\
Feed cost (tk) & 128.00 & 128.00 \\
Miscellaneous (tk) & 20.00 & 20.00 \\
Total cost/broiler (tk) & 178.00 & 188.00 \\
Average live weight (Kg) & 1.640 & 1.920 \\
Sale price/Kg live wt. (tk) & 130.00 & 130.00 \\
Sale price/broiler (tk) & 213.20 & 250.00 \\
Net profit/broiler (tk) & 10.50 & 33.00 \\
Net Profit/ Kg live weight (tk) & 21.46 & 32.29 \\
\hline
\end{tabular}

Supplementation with tulsi extract was more profitable than control group (Table 3) but the difference was not significant $(\mathrm{p}>0.05)$. The study has revealed that supplemented with tulsi leaf extract had higher body weight gain, weekly gain in weight, feed consumption and feed efficiency (Islam et al., 2013). These results may be due to antimicrobial and anti-protozoal properties (Kale et al., 2003) of tulsi leaves, which help to reduce the microbial load of birds and improved the feed consumption and feed efficiency of the birds (Pushpagadan and Sobti, 1977). It is concluded that supplementation $2 \mathrm{ml}$ of tulsi extract/kg poultry ration of treatment groups caused significant increase in live body weight and improvement in weekly gain in weight and feed-efficiency as compared to that of control group of poultry. Our results are in line with those reported by (Siddig and Abdelati, 2001) who carried out a research work in broiler fed rations containing tulsi leave extract showing higher weight gain. In our study, the use of tulsi leave extract showed more increase in live weight of the birds as compared to control, which is also in agreement with the findings of (Samanta and Dey, 1991) who concluded that tulsi may be incorporated as a growth promoter in the ration of Japanese quails. Better feed conversion ratio of the broiler using rations supplemented with tulsi leaf extract may be attributed to the antibacterial properties of these supplements, which resulted in better absorption of the nutrients present in the gut and finally leading to improvement in feed conversion ratio of the rations. This study has revealed that tulsi extract had no significant effect on the hematological parameters (Table 4). This findings, however, does not agree with Nagalakshmi et al. (1996) and Gowda et al. (1998) who reported that bitter principles of medicinal plants possess a strong influence on hematological traits particularly PCV and $\mathrm{Hb}$ of subjects, depending on their nutritional status. 


\section{N. Hasan and others}

Observation of hematological parameters (TEC, ESR, PCV and $\mathrm{Hb}$ ) on $35^{\text {th }}$ day showed significant difference $(\mathrm{P}<0.05)$ between the control and tulsi leaf extract treated groups while $\mathrm{Hb}$ did not show any significant difference compared to control (Table 4). This discrepancy could be explained by two ways. Firstly, the duration of the experiment period could have an influence on the hematological parameters as we know that the lifespan of RBC is approximately 120 days. Our experiment was limited for a short period of time (35 days) in comparison to other's work. Secondly, tulsi leaf extract having no significant effect on the hematological parameters in broiler may suggest that these herbs have no harmful effects, particularly on hematological parameters.

Table 4.Effect of tulsi leaf extract on hematological parameters of broiler

\begin{tabular}{|c|c|c|c|c|}
\hline \multirow{2}{*}{ Blood parameters } & \multicolumn{2}{|c|}{ Average blood parameters value (Mean \pm SEM) } & \multirow{2}{*}{ P-value } & \multirow{2}{*}{$\begin{array}{c}\text { Significance level } \\
(\mathrm{P}<0.05)\end{array}$} \\
\hline & Control & Tulsi & & \\
\hline TEC $\left(\mathrm{mm}^{3}\right)$ & $247.67 \pm 1.028$ & $298.39 \pm 0.751$ & 0.001 & $* *$ \\
\hline $\mathrm{Hb}(\mathrm{gm} / \mathrm{dl})$ & $6.92 \pm 0.491$ & $7.79 \pm 0.111$ & 0.243 & NS \\
\hline PCV $(\%)$ & $18.00 \pm 0.134$ & $19.95 \pm 0.022$ & 0.000 & $* *$ \\
\hline ESR $\mathrm{mm}$ in $1^{\text {st }}$ hour & $7.40 \pm 0.268$ & $5.24 \pm 0.554$ & 0.004 & $* *$ \\
\hline
\end{tabular}

\section{CONCLUSION}

From the findings of the present study it can be concluded that supplementation with tulsi leaf extract @ 2ml/L drinking water causes significant increase in live body weight and improvement in weekly weight gain and feed efficiency as compared to that of control group of broiler. Thus tulsi leaf extract supplementation in the broiler rations may be useful for the safe, economical and efficient production of broiler and this formulation could be used as an alternative to commercial growth promoters. However, further studies are essential to assess the impact of these medicinal plants on the quality of broiler meat and immune status to ensure the safety of human consumption.

\section{REFERENCES}

1. Armstrong DG (1986). Gut active growth promoters. In: Control and manipulation of animal growth. Eds. By Buttery PJ, Lindsay DB and Haynes NB pp. 21-37.

2. Ashayerizadeh A, Dabiri N, Ashayerizadeh O, Mirzadeh KH, Roshanfekr H and Mamooee M (2009). Effect of dietary antibiotic, probiotic and prebiotic as growth promoters, on growth performance, carcass characteristics and hematological indices of broiler chickens. Pakistan Journal of Biological Sciences 12: 52-57.

3. Bhujbal RN, Patil MB, Kank VD, Rande AS, Gadegaonkar GM, Karambele NR, Pawar GA, Salunkhe SC and Chopde SV (2009). Effects of phytobiotics on the performance of broilers. Journal of Bombay Veterinary College 17:33-35.

4. Banerjee LK (1998). Floral status of Buxa tiger reserve, West Bengal. In Plant Diversity in the Tiger Reserves of India pp.71-74.

5. Borris RP (1996). Natural product research: perspective from a major pharmaceutical company. Journal of Ethnopharmacology 5: 29-38.

6. Carmona-Fernandez R, Lopez-Hernandez OD, Gonzalez-Sanavia MLG, Fernandez-Nunez EG and BarzagaFernandez P (2009). Optimizing a process to obtain Ocimum sanctum L. (albacamorada) aqueous extract.Revista CubanadePlantasMedicinales 14: 14-22.

7. Demir E, Sarica S, Ozcan MA and Suicmez M (2005). The use of natural feed additives as alternative to an antibiotic growth promoter in broiler diets. Archivfur Geflugelkunde 69: 110-116.

8. Gatne MM, Ghangale GR and Surve VS (2008). Studies on anti-diarrhoea activity of Ocimum sanctum (Tulsi) in rats. Journal of Bombay Veterinary College 16: 42-43.

9. Gowda SK (1998). Neem (Azadirachta indica) kernel meal in the diet of White Leghorn layers. British Poultry Science 39: 648-562.

10. Hsieh PC, Mau JL and Huang SH (2001). Antimicrobial effect of various combinations of plant extracts. Food Microbiology 18: 35-43.

11. Islam MR, Mostofa M, Roy RR, Sorwar MG and Mondal KS (2013). Role of max yeast culture probiotic in potentiating the growth performance of commercial broiler. Progressive Agriculture 24: 131-136.

12. Jadhav HR, Singh A and Bhutani KK (2005). Rationale for immunomodulatory and anti-inflammatory effect of Ocimum sanctum: radical scavenging potential and effect on nitric oxide production. Acta Horticulture 678: 159162.

13. Juven BJ, Kanner J, Schved F and Weissloweicz H (1994). Factors that interact with the antibacterial action of thyme essential oil and its active constituents. Journal of Applied Bacteriology 76: 626-631.

14. Kale BP, Kothekar MA, TAyade HP, Jaju JB and Mateenuddin M (2003). Effect of aqueous extract of Azadirachtaindica leaves on hepatotoxicity induced by antitubercular drugs in rats. Indian Journal of Pharmacology 35: 177-180.

15. Khanna N and Bhatia J (2003). Action of Ocimum sanctum (Tulsi) in mice: possible mechanism involved. Journal of Ethnopharmacology 88: 293-296.

16. Khatun S, Mostofa M, AlomF, Uddin J, Alam MN and Moitry NF (2013). Efficacy of tulsi and neem leaves extract in broiler production. Bangladesh Journal of Veterinary Medicine 11: 1-5. 
17. Lamberg SL and Rothstein R (1977). Laboratory Manual of Hematology Urinalysis. Avi. Publishing Company, Inc, West Port Connecticut, USA.

18. Mollah MR, Rahman MM, Akter F and Mostofa M (2012). Effects of nishyinda, black pepper and cinamon extract as growth promoter in broiler. The Bangladesh Veterinarians 29: 69-77.

19. Mazhar-IIahi, Jangde CR, Arun-Handa, Waghmare SP and Ajit-Handa (2007). Some pharmacological and phytochemical investigations on aqueous extract of Ocimum sanctum Linn.leaves. Royal Veterinary Journal of India. 3: 137-139.

20. Nagalakshmi D, Sastry VRB, Agarwal D, Katiyar RC and Verma SVS (1996). Performance of broiler chicks fed on alkali treated neem (Azadirachtaindica) Kernel cake as a protein supplement. British Poultry Science 37: 809-818.

21. Nath DD, Rahman MM, Akter F and Mostofa M (2012). Effects of tulsi, black pepper and cloves extract as a growth promoters in broilers. Bangladesh Journal of Veterinary Medicine 10: 33-39.

22. Pushpagadan G and Sobti SN (1977). Medicinal properties of Ocimum sanctum (Tulsi) species and some recent investigation of their efficacy. Indian Drugs 14: 207.

23. Sen P (1993). Therapeutic potentials of Tulsi: from experience to facts. Drugs News and Views 1: 15-21.

24. Samanta AR and Dey A (1991). Effect of feeding garlic (A. sativum Linn) as a growth promote in Japanese quails (C. coturnix japonica) and its influence on dressing parameter. Indian Journal of Poultry Science 26: 142-145.

25. Siddig RM and Abdelati K (2001). Effect of dietary vitamin A and N. sativa on broiler chick's performance. In proceeding: $10^{\text {th }}$ International Conference of Association for Tropical Veterinary Medicine and Livestock.Community and Environment, Copenhagen, Denmark.

26. Singh KS and Panda B (1992). Feed additives. In: Poultry nutrition. $2^{\text {nd }}$ edn. Kalyani. Delhi, pp. 134-143.

27.Vinod-Krishna, Jyoti-Uikey and Saxena RC (2007). Mosquito larvicidal activity of Ocimum sanctum on Culex quinquefasciants.Biosciences-Biotechnology Research Asia 4: 717-720.

28. WHO (1997). Antibiotic use in food-producing animals must be curtailed to prevent increased resistance in humans. Press Release WHO/73, October 20 ${ }^{\text {th }}, 1997$. 